\title{
Authoritarian Control Mechanism over Chinese Intellectuals under the KMT Regime: A Study on Its History and Effects
}

\author{
Lei Gao' ${ }^{1}, \mathrm{Lu} \mathrm{Xia}^{2 *}$ \\ ${ }^{1}$ Collaborative Innovation Center for the Theories \& Practices of Open and Great Economy (建设开放型经济强国理论与实践研究 \\ 协同创新中心), University of International Business and Economics, Beijing, China \\ ${ }^{2}$ Institute for History \& Theories of the CCP, Renmin University of China, Beijing, China \\ Email: gglei9496@sina.com, *luxiaruc@ruc.edu.cn
}

How to cite this paper: Gao, L. and Xia, L. (2018) Authoritarian Control Mechanism over Chinese Intellectuals under the KMT Regime: A Study on Its History and Effects. Open Access Library Journal, 5: e4235. https://doi.org/10.4236/oalib.1104235

Received: December 4, 2017

Accepted: January 6, 2018

Published: January 9, 2018

Copyright $\odot 2018$ by authors and Open Access Library Inc.

This work is licensed under the Creative Commons Attribution International License (CC BY 4.0).

http://creativecommons.org/licenses/by/4.0/ (c) (i) Open Access

\begin{abstract}
After the Kuomintang (KMT) established a nationalist regime on mainland China in 1927, some Chinese intellectuals were recruited into the regime and served at even key positions, whereas others chose to maintain independence and autonomy in order to check the power of the authority. In 1949, the KMT retreat from Mainland to Taiwan with many excellent intellectuals, including both those pro-regime ones and those liberal ones. Due to the variation of the components of intellectuals, the KMT authority adopted different tactics to impose its control over them. By using censorship to the critical-oppositional intellectuals, imposing campus control to the active college students, and establishing political warfare system to restrict pro-government intellectuals, the KMT regime managed to limit the sociopolitical influence of the people among these groups. However, all the strategies and tactics employed by the KMT did not work well enough to maintain its rule during the martial law period; thus, it is appropriate to say that the KMT's social control over intellectuals were not effective to persist its authoritarian rule.
\end{abstract}

\section{Subject Areas \\ History, Politics}

\section{Keywords}

KMT, Authoritarian Control, Pro-Government Intellectuals,

Critical-Oppositional Intellectuals, Active College Students

In 1927, after the North Expedition and other struggles with different warlords, 
the KMT established its nationalist regime centered in Nanjing. Basically, it was an elitist regime led by nationalist revolutionaries and involved by social elites from different categories. A cohort of intellectuals with the Western educational experience gradually became an important force in political arena. Some were recruited into the regime and served at even key positions, whereas other chose to maintain some independence and autonomy in order to check the power of the authority and to improve the whole situation.

In 1949, the KMT retreated from Mainland China to Taiwan with many excellent intellectuals, including both those pro-regime ones and those liberal ones. Due to the variation of the components of intellectuals, the KMT authority adopted different tactics to impose its control over them. There is no doubt that those in favor of the regime are not challenges to the KMT's rule, but some of them as well as most of the center-minded later on have become one of the most serious challenges to the KMT's rule in Taiwan. Student is also a critical force that has played an important role in the resistance campaign against the KMT's authoritarian rule. By using censorship to the critical oppositional intellectuals, imposing campus control to the active students, and establishing political warfare system to restrict pro-government intellectuals, the KMT regime managed to limit the sociopolitical influence of the people among these groups. However, all the strategies and tactics employed by the KMT did not work well enough to maintain its rule during the martial law period; thus, it is appropriate to say that the KMT's social control over intellectuals were not effective to persist its authoritarian rule. This article seeks to investigate the KMT's varied control mechanism over pro-regime intellectuals, critical oppositional intellectuals, and students on campus respectively.

\section{The KMT's Control over Pro-Regime Intellectuals}

Although history saw a lot of movements organized and participated in by the critical oppositional intellectuals and activist students, there were still many intellectuals choosing to serve, support, and operate within the KMT regime. And the regime in return had adopted different strategies to deal with this group of intellectuals. Following a general introduction, two cases, i.e. Chen Bulei and $\mathrm{Hu}$ Shi, will be analyzed in detail to investigate the distinct social control mechanism over these pro-regime intellectuals by the KMT regime.

This article mainly focuses on the KMT's control over intellectuals during its ruling period in Taiwan; however, it is still necessary for us to investigate the KMT's control over the intellectuals, especially those serving and operating within the governing institution, during the Republican period on mainland China. Two reasons can justify this. Firstly, the careers and lives of those intellectuals who chose to stay close to the KMT were continuous before and after they retreat to Taiwan with the regime. Some of them held even higher positions than they did during the Republican period [1]. Spending a little bit more time in exploring the relationship between the KMT and those intellectuals during 
that period may help us deeply understand their experience in Taiwan; furthermore, it may also provide us a whole view of the collaboration and tensions between the state and society under the KMT rule in Taiwan. Secondly, for the KMT, the socioeconomic situations of the Republican period and that of the period in Taiwan were substantially different, which no doubt led to some changes in the party's perception of the intellectuals' roles in society; and this would in turn exert a significant impact on the regime's policies toward intellectuals. Therefore, the distinctions according to different periods may also assist us develop some insight to understand the relationship between the regime and intellectuals. Thus, we choose Chen Bulei as the case for the Republican period, and $\mathrm{Hu}$ Shi as the case for the period in Taiwan.

\subsection{Chen Bulei}

During the Republican period, one of the most important intellectuals that stayed closest to the KMT central leadership, i.e. Chiang Kai-shek, was Chen Bulei, who had been serving as the Generalissimo's Chief-of-Staff, in charge of authoring almost all Chiang's speech drafts and manifestos of the KMT Central Committee, for more than two decades ever since he was chosen by Chiang himself in 1927. Born in 1890 in a big and rich landlord family in Cixi County of Zhejiang Province, Chen Bulei studied Confucian classics when he was still a teenager. In 1907, at the age of 18, he went to Zhejiang Higher Institute (gaodeng xuetang) and studied "new knowledge" there for four years. Before he finished college study and earned a degree, he had already worked for a newspaper located in Shanghai. During transition period after the 1911 Revolution, he stayed Shanghai and managed to establish close relationships with many very important figures in the KMT, such as Song Jiaoren, Dai Jitao, and Yu Youren. Since these figures were all engaged in publication and journalism in order to publicize the ideas and ideologies of national revolution created by Dr. Sun Yat-sen, with their help, from then on, Chen started a journalist career in this field. He had not devoted himself into politics until 1927 when he first met Chiang Kai-shek who admired his writing talent [2] (p. 55).

At his early age, when it was still until the rule of Qing dynasty, Chen Bulei had participated in student movements resisting the imperial system disseminating revolutionary ideas and thoughts. In the fall of 1907, for example, the Imperial Minister of Post and Transportation claimed that all of the railroads in China should be nationalized and built in the name of imperial court. However, the Qing government did not have enough financial ability to maintain its governing capacity, let alone to accomplish all the railway construction; thus, to borrow loans from the Western powers with extra conditions affecting China's integrity of sovereignty and national interests became the mostly used way. In Chen's hometown, Zhejiang province, a planned railroad connecting Shanghai and Hangzhou would be the biggest and the most profitable construction project in this province; although some gentry-merchants were willing to share the 
building cost, the Minister of Post and Transportation still declared that the government would borrow British loans to build the railroad. This action in turn had agitated all related social groups, including gentry-merchants, private entrepreneurs, intellectuals, and college students. They all sent delegates to the capital city of the province to file petition to the imperial governor. Chen Bulei was elected as the delegate of his institute and he actively participated in most of the movement striking for railroads rights in particular and for the nation's better future in general.

After he graduated from Zhejiang Higher Institute in 1911, Chen Bulei continuously worked as a journalist for Tianduobao (天铎报), Shenbao (申报), and Shangbao (商报), all locating in Shanghai. His daily job was to write editorials and comments for the newspapers. Although he was a fledging in journalism, Chen became noted soon by his works. Early leaders of the KMT, including Song Jiaoren and $\mathrm{Yu}$ Youren who became senior leader afterwards, were also working in journalism in Shanghai back then [2] (p. 78). Chen admired their knowledge and experience in the field, so he established close connection with these people. His thought had gradually become prone to sympathizing national revolution led by the KMT, which rendered him easier access to the party's leadership afterwards.

As time went by, Chen Bulei's name had become more and more famous, and he was noted by Chiang Kai-shek, who had become the actual leader of the KMT and had a mind to recruit talent intellectuals to strengthen his party. In February 1927, when Chen Bulei met with Chiang for the first time, the Generalissimo encouraged Chen to join the party and serve the nation. Noticing that Chen was a little bit hesitated, Chiang praised that he had already joined the party spiritually and it would be much better for him to join and serve the party in reality [2] (p. 115). Shortly afterwards, Chen Bulei joined the KMT with recommendations by Chiang Kai-shek and Chen Guofu, head of party organization department. He started his political career first as the secretary for Chiang, and soon was appointed as the secretary-general of Zhejiang Provincial government and of the KMT Central Committee. From 1934 until his death in 1948, his official positions ranged from local level including the Director of Education Department of Zhejiang Province, member of Zhejiang Provincial Governmental Committee, to national level including Deputy Minister of Education, Deputy Director of the KMT's Central Publicizing Committee, Deputy General Secretary of Central Political Conference, Deputy Secretary of National Defense Conference, and Consultant for President Office. Not only did he have to read over and give marks to official documents, but he also needed to serve as the liaison officer between Chiang Kai-shek and the KMT Central Committee and to draft speeches for the leader [2] (p. 13). Besides, he also served as the special guest commentator for a couple of newspapers, regularly writing propagandist essays for the newly founded KMT regime in his spare time. Offering Chen Bulei higher and key positions to make full use of his specific talents was an important 
control tactic used by Chiang back to the Republican period.

During his term as the Deputy Minister of Education (from 1931 to 1932), Chen Bulei carried out the KMT's control policies over intellectual community with himself being the implementer. The fields he paid most attention were dealing with increasing student movements in northern China due to the imminent Japanese invasion and regulating colleges and universities administration, including disbanding National Labor University, firing Professor Luo Longji from Guanghua University, and disbanding Beijing Russian Institute for Laws and Politics. As the major officer in educational and propagandist affairs, dealing with oppositional intellectuals and student movements and rival political forces became one part of Chen's job, and by accomplishing these jobs, not only did he help the KMT authority root out rival forces, but he also put himself in a position easily being controlled.

In May 1934, Chen Bulei started to reach the apex of his career by serving as the Director of Designing Committee for Chiang Kai-shek's headquarter in Nanchang, Jiangxi province. The aim of establishing the Design Committee was to provide a channel and platform for Chiang to recruit and gather excellent returned oversea students and to train them as his private secretary pool and reserve cadres [3]. Chen's talents in dealing with intellectuals and administrating propaganda was valued by the Generalissimo and appointed as the officer-in-charge of this de facto private secretaries group. Later on, when Chiang's headquarter was closed down, this Designing Committee subsequently transformed into the Assistant Office of the General-Director (zongcai shicongshi) which had two sub-offices in charge of military and party affair respectively, and Chen Bulei accordingly became both the director of the Assistant Office and the head of the second sub-office whose major job was to assist the Generalissimo with drafting documents as well as collecting and researching information [4].

In late 1935, the KMT convened its fifth national congress in Nanjing. This congress saw the promotion of Chen Bulei to the highest position ever in his political career. Immediately after the congress, the newly-elected Central Executive Committee (CEC) was convened; a couple of critical positions have been decided is this convention, including appointing $\mathrm{Hu}$ Hanmin as the Chairman of the Central Standing Committee of the CEC, appointing Wang Jingwei as the Chairman of the Central Political Conference of the CEC, appointing Chiang Kai-shek as the Vice-Chairman of both the above organs, and appointing Chen Bulei as the Deputy General Secretary of the Central Political Conference, which was the supreme organ of the political power in the KMT's regime [5]. When Sino-Japan war broke out, the Supreme National Defense Committee, with Chiang Kai-shek as the Chairman, was established and functioned as the de facto supreme organ of political power; due to his growing contribution to the KMT's propaganda work and increasingly important position in Chiang's mind, Chen Bulei was appointed as the Deputy General Secretary of the Supreme National Defense Committee, in charge of all the documents drafting as well as informa- 
tion collecting and categorizing [2] (p. 173).

From this point on, until his death (suicide in 1948), Chen Bulei had been serving as the major assistant with decisive position for the KMT's supreme political leadership in general and Chiang Kei-shek in particular. He started his career with journalism immediately after his graduation from higher institute without going abroad to pursue western thoughts, and then joined the KMT's revolutionary cause by contributing his intellectual talents to the party's propagandist work as well as educational affairs. From his not long but dramatic career path, we could catch a glimpse of the KMT's control mechanism over intellectuals during the Republican Period that could be labeled as "mild control and cooperation". As it will be shown in the rest of this sector, most of the intellectuals who chose to retreat to Taiwan with the KMT regime shared some common experiences with Chen during the Republican period. Nonetheless, no matter how close those intellectuals stayed to the party, the KMT leadership, particular Chiang Kai-shek himself, gradually changed the attitude and strategy toward this group of people due to the party leadership's perception of the intellectuals' potential challenge. And this trend of perception was much easily to gain from those who had oversea experiences, such as $\mathrm{Hu}$ Shih, Luo Jialun, Sa Mengwu, and Hu Qiuyuan.

\subsection{Hu Shi}

Hu Shi, former president of Peking University and Chinese Ambassador to the United States [6], was the spiritual and practical leader of Chinese liberal intellectuals. After he just returned to China in 1917 and served as the professor of Peking University, Hu Shi soon become one of the champions of new culture during the May Fourth Movement in early Republican period [7] [8]. He had proposed and publicized liberalism and democracy and harshly criticized dictatorship in China for a long period; although he declared openly that he would not talk about politics for 20 years, he finally chose to serve as Chinese Ambassador to the United States at very late age of the KMT's rule in mainland China. Due to his unavoidable close relation with the KMT leadership, Hu Shi's name was on the list of civil war criminals proposed by the CCP in early 1949 [9].

Wherever he was, basically speaking, $\mathrm{Hu}$ Shi always chose to continuously offer his loyalty and support to the KMT regime and Chiang Kai-shek, which had never been changed. What he said mostly at the time when the Communist swept mainland were "I choose to stand with Mr. Chiang when the nation is in danger" and "I am willing to support Mr. Chiang's government with my morality" [6] (p. 2). Sometimes when facing his scholar fellows' persuasion, he replied "if I don't support the KMT's government, which else should I support?" [6] (p. 21). Notwithstanding his loyalty and support, $\mathrm{Hu}$ Shi at times expressed his concern with the future of the regime, especially the implementation of the constitution, the establishment of modern competitive party system, and the guarantee of freedom of speech and association, which suggested the liberal thought 
deeply in his mind.

Basically, Chiang Kai-shek and the KMT leadership showed their respect to $\mathrm{Hu}$ Shi, since he had been worldly famous early and for a long period, even earlier than the KMT consolidated its rule on mainland China, and had extensively and intensively close connection with US which could be relied on. Not only did the KMT leadership respect him, but they also co-opted him into the regime to serve the nation. Three important reasons could be the explanation. First, essentially speaking, $\mathrm{Hu}$ Shi had an anti-Communism thought [10] although $\mathrm{Hu}$ sometimes published very harsh criticism toward the KMT, Chiang Kai-shek and other party leadership always tolerated him and saw him as the an important ally without divergence in principle, a pure intellectual asking for some freedom and autonomy. Second, the KMT leaders held a perception that by co-opting people like Hu Shi it could improve the state image in the international community by adding colors of liberalism and democracy to the authoritarian regime, advantaging it to establish close relationship with the Western democracies [11]. Third, comparing with his international personal resources, Hu Shi's thoughts resources, especially his opinions on moderate reformist approach, seemed more attractive and valuable to the KMT, which had gradualism legacy in its history [12] and many other liberal intellectuals who concurred about $\mathrm{Hu}$ 's approach such as Fu Sinian and Luo Jialun also chose to support the KMT and serve its regime.

In reality, Hu Shi did not immediately go to Taiwan after 1949; rather, he went to the US and lived in New York without decent jobs and social status for almost ten years, and in 1958 he finally returned to Taiwan to serve as the President of Academia Sinica. Despite the favorable treatment he received in Taiwan, the last few years of 1950s still saw two critical campaigns aiming at him on both sides of the Taiwan Strait, for the ironically similar political goal. From 1949 on, although he was not in Taiwan, Hu Shi served as the publisher and spiritual leader of the Free China Fortnightly. At first, led and ran by a group of slightly pro-KMT intellectuals, this magazine functioned as a publicizing tool for the regime's anti-Communism propaganda. Later on, more and more articles that advocated liberalism and criticized authoritarianism began to emerge in the magazine, which gradually exceeded the KMT regime's tolerance. Finally, in 1960, the authority forced Free China to close down and imprisoned Lei Zhen, editor-in-chief of the magazine and a senior KMT party member, under the charge of "espionage and sedition". Due to his close connection with the magazine, $\mathrm{Hu}$ Shi unavoidably got criticized from the authority, but this time was indirectly.

Before long, in 1961, in his public speech titled "Social Changes for Scientific Development", Hu Shi highly evaluated Western culture and excoriated oriental civilization, which ignited another wave of critical campaign aiming at him. Participating in by a lot of famous specialist on traditional Chinese culture, this campaign was directly against him and more harsh than the one happened just two years ago. Superficially, the second critical campaign was purely about the 
debates on culture, but from the background of the scholars who wrote critical articles, including Xu Fuguan, a former secretary of Assistant Office of the General-Director, Hu Qiuyuan, former chief-editor of Central Daily and member of Legislative Yuan, Ren Zhuoxuan, former Deputy Head of the KMT's Central Propaganda Department and a CCP-called civil war criminal, and Zheng Xuejia, a senior political economists close connecting with the KMT central propaganda department, we could clearly see the trace of the authority [12] (pp. 20-24).

In spite of some criticism, sometimes even harsh, this group of intellectuals, like Chen Bulei and Hu Shi, never sought to challenge the KMT's legitimate rule. $\mathrm{Hu}$ Shi said to those who planned to organize oppositional forces before that "never take unpeaceful approaches and hostile attitude toward the authority, since it can beat you down before you can overthrow it" [6] (p. 21). Therefore, it is appropriate to argue that the KMT's control mechanisms over pro-regime intellectuals suggest a mild-control with the intension of utilization. And the attitudes toward the regime shape the government responses.

\section{The KMT's Control Mechanisms over Critical Oppositional Intellectuals}

After the government of Republic of China retreat to endure its rule in Taiwan following the World War II, the distinction of having the longest period of martial law in modern history was imposed on Taiwan. In the aftermath of the February 28 Incident of 1947, martial law was declared in 1948 despite the democracy promised in the Constitution of the Republic of China. After the KMT government lost control of its possession in mainland China to the Chinese Communist Party (CCP) and retreated to Taiwan in 1949, the perceived need to suppress Communist and Taiwan Independent activities in Taiwan meant that the martial law was not lifted until 1987. Functioning as an authoritarian regime, the KMT authority had used varied social control mechanisms over different kinds of groups to secure its rule. This article examines the KMT's control over intellectuals during the martial law period, with a focus on the incessant suppression of typical publications and the intellectuals associated with them.

Specifically, during the martial law period, the authority held two basic types of censorship powers that severely restricted the constitution's guarantees of freedom of expression. Martial law itself permitted the Taiwan Garrison Command Headquarter to ban any publication "deemed prejudicial to... military affairs". In addition, the Publication Law permits the authority to seize or ban any material which "confuses public opinion and affects the morale of the public and armed forces", or which commits or instigates others to "commit sedition, treason, offenses of interference with the lawful exercise of public functions of against public order" [13]. These transgressions are so vaguely defined that the law basically allows the regime to suppress whatever it dislikes. Basically, there were five types of censorship action by the authority: denial of licenses, suspension of licenses, confiscation of an issue, banning of an issue, and censorship of 
part of an issue [13] (p. 143).

Generally speaking, we can divide the whole period of the KMT's rule (the Martial Law Period) in Taiwan into three stages with each one having a representative publication and a group of intellectuals: first, 1949-1960, typical case was Free China Fortnightly Incident; second, 1961-1973, typical case was Wen Xing \& Da Xue Incident; and third, 1973-1987, typical case was Formosa the Kaohsiung Incident.

\subsection{First Stage, 1949-1960}

Free China Fortnightly, established in November 1949 in Taipei by a group of intellectuals inherited the liberal tradition from Mainland to Taiwan. The magazine reprinted its founding principles in each issue: promoting democracy and democratic values in the ROC, fighting communist expansion, battling for freedom of Chinese living under communism, and making all of China Free China [10] (p. 55). At its early stage, the magazine had very close relationship with the KMT, economically and politically. As for economic relationship, Free China was financed about 500 US dollars monthly by Ministry of Education and an office building by Taiwan provincial government. As for political relationship, it was initially viewed and actually used by the KMT as its important United Front publication to attract members of "The Third Force Overseas", of which most people were liberal intellectuals, as well as a publicizing tool to resume the KMT's international image [14].

As the time went by, the international situation became less urgent and the KMT strengthened its domestic control over Taiwan society, Free China and the intellectuals associated with it got suppression due to its continuous criticism about the KMT's authoritarian rule. In Jan 1955, Lei Zhen, the editor-in-chief of Free China, was expelled from the KMT because of his tolerance to an article aiming at Anti-Communist National Salvation China Youth Corps' (fangong qingnian jiuguotuan) intervention of normal educational order, especially secondary schools [15].

From 1959 to 1960, Free China participated into the debate on the issues of revising constitution which made the tension between itself and the KMT even fierce [14] (p. 59). In 1954, according to the Constitution of ROC, Generalissimo Chiang Kai-shek was elected as the President for the second time. However, not only Chiang himself but also some of his loyal supporters would like to attempt to extend the term of president when it approached to the end of his second term. Free China held its clear-cut constitutional position and opposed that attempt by publishing a series of articles discussing about the issues of revising constitution.

Free China suffered suppression was not only because of its theoretical criticism to the KMT, but also because of their actual political participation cooperating with some local elites [14] (pp. 70-78). In July and August 1957, an attempt to establish an organization named China Local Autonomy Research So- 
ciety failed for the second time after the $3^{\text {rd }}$ Municipal Executives and Provincial Assembly Deputies Elections in Taiwan. This organization was initiated by a group of non-KMT elites who won the abovementioned election. From this event on, Free China started to focus on local politics and election. Hu Shih, the spiritual leader of Free China and the author of its founding declaration, publicly called for intellectuals to organize an opposition party to balance the KMT [14] (p. 72).

In 1960, after the local election, i.e. the $4^{\text {th }}$ Municipal Executives and Provincial Assembly Deputies Elections in Taiwan, an attempt to establish a new party was resumed and Lei Zhen, as the editor-in-chief of Free China, devoted his magazine and himself fully into this activity. An organization called Local Election Improvement Association was established by a number of political activists who shared some overlap membership with the attempt three years ago. Lei Zhen was elected as one of the collective leadership. This organization clearly declared that one of their important maims was to end the one-party dominance and to establish true democracy.

There was a noteworthy fact that Free China was but one liberal-oriented publication that both disseminated the idea of opposition party and inspired the activity of that back then. The others included Democracy Tide (minzhuchao), the organ of China Youth Party, and Taiwan People Power News (gonglunbao), one of the only two private newspapers and the most popular publication during 1950s [14] (p. 73). Therefore, it is appropriate to argue that Free China magazine as well as the intellectual community around it have already got involved into the public challenge to the KMT's authoritarian rule. And they would unavoidably be repressed. On Sep 4, 1960, Lei Zhen and an editor of Free China were arrested under the suspicion of subversion and treason. The magazine was also sealed up. Finally, in October, Lei Zhen was sentenced to 10-year imprisonment.

\subsection{Second Stage, 1961-1973}

Wen Xing (Apollo), established by Xiao Mengneng in 1957, was the most prominent and enlightening magazine during late 1950s and early 1960s. Originally, it was designed not as a political magazine but a literature one. However, since November 1961, Li Ao, one of the most important and influential intellectuals in modern Taiwan, had joined the editorship, the magazine had transformed its focus from literature to intellectual debate, especially in the way of criticizing Chinese traditional culture and advocating modern and western thoughts. Moreover, since August 1962, the magazine had started concerning with contemporary political, social, and legal issues as well as disseminating the concepts of liberty, democracy, rule of law, and human rights. Thus, the conservative forces started to suppress Wen Xing group.

Basically speaking, Free China was a magazine primarily published political comments and essays that publicized democracy and liberty; whereas, Wen Xing was a more culture-oriented one mainly published intellectual critics that spread 
enlightenment thoughts once popular in May Fourth movement. Three reasons could explain the phenomenon then: First, during May Fourth era, there were two major approaches to be used to criticize the real political life, i.e. socialism and liberalism. After the KMT government retreated to Taiwan, only liberalism could be spread. Thus, the critical legacy of liberalism was inherited by the younger generation in Taiwan. Second, although liberalism could be talked and discussed in public, the KMT authority still attempted to label it as a backwash thought and to weaken the influence of May Fourth and liberalism. Against to this trend, a few intellectuals influenced by May Fourth movement before began to write articles in memory of that significant event. Third, Taiwanese society in 1950s were still very traditional, and liberalism and May Fourth become important intellectuals source to alter the situation that hindered the local economic development [16].

In December 1965, because of its harsh criticism toward the KMT authority and enthusiastic dissemination of western thoughts, Wen Xing was banned. The trigger of its being ban was an article by Li Ao, its then editor-in-chief, sternly denouncing that Xie Ranzhi, the KMT's propaganda chief, had violated Chiang Kai-shek's instruction that "do not suppress other opinion by authority" [17].

Da Xue (the Intellectual) was founded in 1968 and initially it was not a political-oriented magazine either. In 1970, Da Xue's editorship was re-organized and added into a lot of younger intellectuals who were born after Sino-Japanese War. Because of the political issues in 1971 such as Senkaku Island Dispute and Taiwan being expelled from the United Nations, Da Xue started to pay more attention on political and international issues and most of its contributors were intellectuals with professional background.

Actually, another deep political background for the rising of Da Xue should not be ignored. At that time, Chiang Ching-kuo, son of Chiang Kai-shek and the then vice-president of the Executive Yuan, was about to ascend to a higher status and to assume more significant power. In order to create a relax atmosphere and gain support from younger generation to secure the smooth transference of power, Chiang Ching-kuo and his staff managed to invite a few younger intellectuals and private entrepreneurs to share their opinions about current issues. Under this circumstance, Da Xue's editorship was reorganized and a few younger intellectuals and private entrepreneurs such as Zhang Shaowen, Chen Guying, Chen Shaoting, Qiu Hongda, and Yang Guoshu joined this magazine.

After this reorganization, Da Xue had taken on a new look. In October 1971, the date that marked the $60^{\text {th }}$ anniversary of the foundation of ROC, the magazine published two far-reaching long essays, i.e. An Analysis of Taiwanese Social Forces by Zhang Junhong and $\mathrm{Xu}$ Xinliang (future prominent leaders of non-Party movement) and Opinions on State Issues by Yang Guoshu and other 15 authors [14] (pp. 95-97). Both of the essays strongly suggested the KMT authority to take the advantage of those social groups with potential and to carry out real reforms in different aspects, including developing private economy, es- 
tablishing rule of law, and opening the society. Of all their proposals and criticism, the most critical was the one toward legitimacy and representative bodies in the national level (deputies in National Assembly and Legislative Yuan). From their point of view, the deputies being elected more than twenty years ago could not represent those then younger generation who were born and living in Taiwan. Moreover, despite some achievement in economic development, they thought Taiwan was in need of political reform.

In January 1972, as a symbol of celebrating the $4^{\text {th }}$ anniversary of Da Xue magazine, the same group of author collectively wrote a long essay titled Nine Opinions on State Issues expressing their opinions on the following aspects of state issues: respecting and protecting human rights, reforming personnel system, changing foreign policy, developing economy, assisting agriculture, establishing social welfare system, reforming education, promoting local autonomy, and cultivating younger generation [14] (pp. 99-103). Not only did those intellectuals write essays to criticize the authority and suggest change the stagnated situation, but they also went down to university and college campuses to organize real activities. In mid-1972, the KMT launched supplementary election for the representatives in the national bodies; responding to this, the intellectuals organized a couple of Seminars on Central and Local Elections [18]. This activity in reality tested the tolerance of the KMT regime. Chen Guying, one of the authors of the long essay and a young philosophy professor at National Taiwan University, called on college students to participate in real politics by organizing and participating in students' movement. Chen and other activists among teaching staffs and students were immediately detained by Taiwan Garrison Command Headquarter. Later on, 14 teaching staffs of NTU's philosophy department, including Chen Guying, were fired because of their radical thoughts and behaviors [18] (p. 106). This event saw the de facto end of Da Xue magazine.

The declining of $\mathrm{Da}$ Xue magazine could be viewed as the consequence of the KMT's manipulation. Before Chiang Ching-kuo and a group of younger elites successfully assumed power, they tended to invite and ask the intellectual community to create a more relax and liberal atmosphere; whereas, once they succeeded in assuming the authority, they preferred a more stable and ordered situation. From their point of view, Da Xue magazine was no more than a tool to help them mold public opinion. Unfortunately, however, they never expect $\mathrm{Da}$ Xue really dared to spread some thoughts that they disliked.

\subsection{Third Stage, 1973-1987}

From mid-1970s on, non-KMT oppositional movements began to rise. In 1975, a new magazine named Taiwan Political Review existed for just five months, but it linked the preceding period of Da Xue and the succeeding period of Formosa. This magazine was created and run by Provincial Assembly non-KMT members such as Kang Ningxiang, Zhang Junhong and Huang Xinjie, most of them younger intellectuals. Not only did Taiwan Political Review inherit the critical 
legacy of preceding Wen Xing and Da Xue, but it also created a new trend that intellectual work and real politics closely associated with each other.

The year of 1979 saw the appearance of two important intellectual publications, i.e. The Eighties Monthly and the Formosa. The former was created and led by Kang Ningxiang, while the latter by Zhang Junhong and Xu Xinliang. These two major magazines had played a critical role in mobilizing and organizing non-Party movements against the KMT's dominance in politics. However, the two magazines represented two major different resistance lines. The Eighties Monthly led by Kang Ningxiang took a moderate and rational line focusing more on molding public opinion and preferring working within the system for gradual change, whereas the Formosa and the intellectual community associated with it unswervingly adopted a radical line focusing more on mobilizing mass to take to the street and preferring violent resistance. Two different ways led to different destinies. Formosa Incident (or Kaohsiung Incident) was the typical case of violent resistance by non-Party intellectuals and harsh crackdown by the KMT regime.

The Formosa group's ambitions extended beyond publishing; they hoped to make full use of the magazine as the vehicle for an island-wide quasi-party [18] (p. 111). In September 1979, they open the first Formosa service center in Kaohsiung city. The office took its name from the constituent service offices operated by nearly all politicians in Taiwan. They planned to open 12 centers throughout the entire island. These centers were to serve as headquarters for demonstrations and grassroots organizing. On December 10, the Formosa group sponsored a rally commemorating International Human Rights Day. The demonstration was held in a square in downtown Kaohsiung city. The thousands of marchers found the exits blocked by riot police. Although there is no consensus about what happened next, violence erupted eventually.

The KMT regime's reaction was swift and severe. All of the Formosa magazine staffers were arrested, so were some oppositional intellectuals and activists associated with it. Eight of the Formosa staffers were court-martialed on sedition charges including Huang Xinjie, Zhang Junhong, Yao Jiawen, Chen Ju, Lv Xiulian, etc. Other 33 activists faced trial in civilian courts.

Because of the court-martial and civilian trail of the oppositional intellectuals, the whole 1980s experienced a less enthusiastic circumstance than 1970s, despite some election-oriented intellectual groups' establishment and activities. A noteworthy trend in 1980s was that a new generation of oppositionists that adopted more radical lines began to grow up. Association of Non-Party Editors and Authors, an oppositional group established in 1983, was a typical group that tried to identify themselves away from those incumbent non-Party activists like Kang Ningxiang and their organization, Association for Public Policy Research. However, both of the organizations were illegal back then. The KMT authority threatened to shut them down by force.

Moreover, different kinds of magazines emerged like the mushrooms after 
rain. Most of these magazines were created by incumbent legislator and assembly members to publicize their performance of inquiry in legislature. Due to fierce competition, these magazines started declining in their editorial and publishing quality. And most of them published inside information, hearsays, and even rumors to increase their circulation. And this caused a lot of these magazines to be banned quickly by the authority and to become short-lived publications. In short, between Kaohsiung Incident in 1979 and the end of martial law in 1987, the KMT regime stepped up censorship action both quantitatively and qualitatively [13] (p. 141).

The division within oppositionist needs more attention here. The division within non-Party movements between radical faction (Huang Xinjie) and moderate faction (Kang Ningxiang) existed for a longer period, even before Kaohsiung Incident, due to their different strategies and lines. In 1980s, the radical legacy was carried forward by a group of new generation oppositionist, consisting primarily of lawyers like Chen Shuibian and authors like Li Ao. In 1985, the moderate faction and the ruling elite held a negotiation mediated by a group of neutral professors. Despite no substantial progress, the negotiation was a good starting point of understanding and communication between the regime and the oppositionists. However, the radical faction was dissatisfied with this negotiation, labeling it as betraying. Not only did they attack their own fellows within oppositional camp, but they also scold those professors who did the mediation. In May 1986, Penglaidao, a radical magazine that published a lot of articles spread radicalism and intransigence, was banned in the charges of slander and its major staffers, Huang Tianfu, Chen Shuibian, and Li Yiyang, were arrested and sentenced eight month imprisonment.

\section{The KMT's Control Mechanism over Students on Campus}

Since its retreat to Taiwan, the KMT has carried out greater control over university and college students than any other social sectors except the labor forces. This is because the KMT has learnt the lesson that leftist activities on campus have played key roles in impairing its rule on mainland China [13] (p. 172). Thus, along with its party re-organization and economic development policy, the KMT regime attempted to restore its tight restriction on students and campus life. Basically, the control over students varied in different education levels.

At the elementary and secondary levels, the KMT authority exercised immediate and direct control through two approaches, i.e. the school curriculum in the content and the functional organization in the form. At the elementary and secondary schools, the curriculum and pedagogical methods were aiming at indoctrinating the KMT's ideological propaganda. All the students were required to learn huge amounts of this kind of materials, including the teachings of Three Principle of the People by Dr. Sun Yat-sen, by rote. Few students were really interested in this kind of boring and stuffy knowledge; however, if they wanted to gain admittance to Taiwan's colleges and universities, they must pass a stiff na- 
tional standardized examination based on primarily on those indoctrinations. Beginning in junior high and intensifying at their senior high level, students had to spend most of their time in school, doing homework, and attending supplemental "cram schools" to prepare for exams. Before the entrance examinations, students had to face years of weekly testing and daily quizzes [13] (p. 174).

Besides the control on the content, the KMT regime also imposed control over some certain functional organization aiming at co-opting students. When they were in high school, excepting intensive academic pressures, the students also must contend with serious KMT recruitment. Students, especially those in secondary schools, were strongly encouraged to join the Anti-Communist National Salvation China Youth Corps (fangong qingnian jiuguotuan), the youth affiliated organization of the KMT which was established by Chiang Ching-kuo and explicitly modeled after Hitler Youth and Soviet Youth Communist League. Through the Youth Corps, the KMT managed to impose control not only by channeling the academic elite into the establishment, but also by encouraging its members to report on any deviant thinking by fellow students and teachers [13] (p. 175) [19]. All these approaches made the atmosphere on high school campuses depressing.

Students at college and university level experienced somewhat different approaches of control by the KMT authority, though the party expected the same effects as at the lower education levels. The most critical approach that the KMT had applied was operating student party cells at all post-secondary institutions. Similar with the function of Youth Corps in high schools, not only did these student party cells frequently co-opt best students into party organizations, but they also encouraged student party members to engage in surveillance of other students and faculty members. Moreover, the KMT also controlled the student unions in colleges and universities, assuring pro-KMT students being elected as presidents and the like.

In addition, all students at public colleges and universities must participate mandatory reserve officers' training [20]. In every school there was an instructor, known as jiaoguan in Chinese who was attached to and dispatched by the Political Warfare Department of the Ministry of National Defense, present in charge of the training. As campus military instructors, not only did they teach students the basic principles of military techniques and elements of strategy, but they also carried out instructions in anti-communism and further required course work of "Sun Yat-senism". As result, in the campus, military instructors were also in charge of reviewing and censoring students' publication that tended to express their "outspoken" ideas and "independent" thinking. Moreover, the Ministry of Education also played an important role in the restricted control over university campuses. It had oversight over each university's president, who in turn controlled the chief and vice-chief disciplinary advisor. Below this level, an Extracurricular Committee oversaw each department's administration. Each of the students was assigned by to a KMT-affiliated "counselor" (also called jiaoguan) 
who lived with them in the dormitory and kept close records on their actions and behavior. Also, each class had at least one unidentified class spy whose job was to scout prospective party recruits and keep an ear to the ground for anti-party opinion and activities [21] [22] [23]. As mentioned earlier, the KMT also utilized its organization construction as a key tactic of campus control. Students who accepted an invitation to join the party typically were rewarded with benefits, such as greater tolerance of poor marks. The KMT recruits also were promised career advantages upon graduation during the period when job opportunities were highly dependent on one's connection with party-state. If any misbehavior was discovered by the counselor, he or one of the higher-level bodies could issue the student a verbal warning, a small demerit, or a large demerit. These punishments had an accruable tendency: three verbal warnings would lead to a small demerit; in turn, three small demerits would result in a large demerit; and at last, three large demerits would cause expulsion [24].

From time to time, with the sponsorship and approval of the KMT, students could form organization and participate in student society activities. Basically, at all universities the Student Union chair was chosen with no direct participation of the whole student population. Rather, nomination and selection of the candidate were largely maintained in the hand of university authorities or the KMT-sponsored student groups or both. Those KMT-affiliated student societies also maintained control over student activities' subsidies and grant nominations [24] (p. 988).

There is no doubt that the KMT regime has also applied severe repressive policies, such as detainment, imprisonment, and even torture, to the students on campuses. In 1960s, outspoken students disregarding military instructor's warning were sometimes jailed for sedition; often their crime consisted of nothing more than advocating academic freedom or democracy [13] (p. 176). Actually, during 1950s and 1960s, most of the students who sought to break out of the narrow confines of the KMT's control by organizing independent study groups without permission from authority faced jail terms in Green Island, a small outlying island southeast to Taiwan Island [25]. Chen Guying, a young philosophy professor at National Taiwan University and a champion who applied Marxist social and political concepts to analyze the situation in Taiwan, called on college students to participate in real politics by organizing and participating in students' movement. Not only Chen himself, but also other activist teaching staffs and some radical students were immediately detained by Taiwan Garrison Command Headquarter in 1973 [14] (pp. 95-97). The KMT regime even imposed the death penalty (later commuted to long jail terms) over a group of students at Cheng Kung University, a less prestigious public university locating in Tainan City, for reading and discussing leftist books and allegedly forming a "revolutionary group" [13] (p. 179). Even students who joined social science team and did survey of rural impoverishment were attacked as "Marxist" and banned to pursue any further social research. 
As for radical students who joined oppositional non-Party movements and worked in campaign and publication, the university authorities took such stern action like expulsion. The case of the expulsion of $\mathrm{Li}$ Wenzhong (Lee Wen-chung) by NTU was the typical one in 1980s [13] (p. 182). Before his expulsion in 1986 by his home university, Li had already participated in a lot of dissident movements as a student leader. One of the influential movements he took part in was the February 28 protest in 1983 in memory of the 2.28 Incident, the blood military suppression of Taiwanese civilians by the KMT troops on February 28, 1947 [26]. Back then, public discussion of the suppression was largely censored in Taiwan, but $\mathrm{Li}$ and his friends were determined to organize a dialogue with activist students from other colleges and universities despite the high probability of serious punishment. In addition, they also printed leaflets that described the suppression and demanded a public recollection of the event, and their fellow students clandestinely help them distribute the leaflets on other university campuses. They also went to the residence of the KMT officials who should be-at least they thought should be-responsible for the suppression to shout slogans and hang banners. As mentioned earlier, there were three less severe kinds of punishment toward college students before the final expulsion. Because of his involvement in the February 28 protest and other previous movements, Li had already accrued two large and two small demerits; this made him be in a probation status, the last one step before final expulsion.

In March 1986, as a senior of NTU majoring in political science, Li finally gained expulsion from university administration, and the official reason was that he failed English II, a required course for his BA degree, for three times consecutively. However, Li himself claimed that it was because he had devoted most of his time and energy to oppositional activities instead of his own academic work that he got this punishment, and he believed the punishment was a political reprisal. In reality, he was indeed an activist; outside the campus he had worked in non-Party campaigns and for an oppositional magazine, while inside the campus he had also made lots of efforts to guarantee the free and fair election of the Student Union. As for the English course, Li claimed that he had not even enrolled that course, not to mention failing for three times. But the NTU administration said that Li had registered the course improperly, therefore accidentally enrolling the course, causing the computer to fail him automatically when he did not receive a grade from the lecturer. The NTU administration then had no more explanation and expelled Li according to the university regulations [5] (p. 95).

$\mathrm{Li}$ was for sure to refuse to accept this punishment and he fought back soon by filing petition to the NTU administration as well as to the Ministry of Education for reconsideration of his case. In addition to those normal channels, he also organized campus protests that attracted several hundred participants and on-lookers. Up to this point, Li's case had already been beyond campus activity due to his efforts and it had attracted the attention of opposition law-makers and such media as Independence Evening Post (zili wanbao). Under the increasing 
pressure, the NTU administration agreed to appoint a faculty committee to evaluate Li's situation; later, this committee recommended that the university re-admit Li on probation, since his procedural misoperation did not warrant the expulsion. However, Professor Sun Zhen, the then NTU president, rejected the committee's recommendation and upheld the original official decision.

Two months later, in mid-May, Li and his supporters launched another demonstration outside the NTU administration building to make their claim of freedom in the campus and to criticize the KMT's manipulation in the election of the Student Union representatives. For maintaining a normal order for education and research, the authority had called in police to break up the rally. Several student protesters got injured in a clash with the police forces. The regime's repressive efforts did not scare Li and his friend, and on the next day they continued their activities including leafleting and demonstrating. At last, this event ended up with Li's induction into the military force by official arrangement.

As for those moderate students who tended to use campus media force to cover and reveal the negative impact of the KMT's control, the university authorities correspondingly adopted mild punishment. The case of the University News was a typical one. Founded as an official news-oriented student organization, the University News was initially supposed to function as the propaganda tool of the NTU authority. But unfortunately, the University News had been found in almost all the activist, if not dissident, student movements throughout 1980s [24] (p. 996). In 1982, it started to discuss the "popular election" topic as opposing the restriction on the choice of the Student Union representatives. Although the NTU authority, particularly the university screening committee, rejected its proposed draft, members of the University News still distributed unreviewed leaflets around campus during the NTU's new student orientation in October, calling for a popular Student Union election and student autonomy. In spite these efforts, the KMT-affiliated chair was reelected. Student groups that participated in disseminating the idea of popular election, such as the University News, were forced to make thorough changes to their organizations and some of the student leaders received different kinds of punishment.

In 1984, unaltered severe campus restriction led the resignation of the KMT-affiliated Student Union chair with reform-minded, the University News distributed copies of a blank newspaper, with an explanation stating that the KMT censorship precluded the printing of the articles that had been prepared. Dubbed the "White Paper Protest", this action triggered a new wave of increasingly provocative student protest activities calling for campus reform. For participating in this activity, the leader of the University News received one large demerit [21] (p. 33).

In 1985, some pro-reform Student Union representatives from different academic background took action to support the direct election of the Student Union chair. They also proposed a plan for the implementation of popular election. However, Professor Sun Zhen, the then NTU president, roundly criticized this 
proposal and also noted that those representatives had no legal power to implement any of the proposals it drafted. Li Huan, the then Minister of Education of ROC, concurred with President Sun in a public declaration about the Student Union election. In protest, the University News openly discussed the feasibility of the implementation of that plan and criticized the "dictatorial" mindset of the university authority. For this act, the editor-in-chief of the University News received one large demerit.

In 1986, the University News published a report of the protest against the building of the Du Pont chemical plant in Lukang (鹿港) without submitting it to the university screening committee [27]. This report assessed the social and environmental impact of the proposed chemical plan, the protests against it, and the relationship between the company and the KMT regime, based on field work during the summer of 1986. In September, the committee rejected the University News's issue of that month, explaining that it was the punishment for unscreened articles published amid the frenzy over Li Wenzhong's expulsion. Later on, the university administration imposed the punishment, suspending the University News as a student organization and ordering its leaders to write statements describing their precise roles and activities within the organization. In response, Wu Jianmin, the chief-writer of the University News, called for his fellow students to support him and his organization. Despite their efforts, even including filing petition to President Sun, the University News was ordered to halt activities for one year and some of its leadership received one or two small demerits [13] (p. 182).

\section{Conclusions}

In light of previous works in the field of intellectuals, the interaction between the KMT and Chinese intellectuals could be analyzed through the perspective of intellectual-state relations [28] [29] [30] [31]. The existing theoretical explanations on the patterns of intellectual-state relations appear to be exclusive and self-subsistent; these distinct arguments actually share a common assumption that the social structure on which the intellectual-state relations may build is a monolithic whole and one type of social structure can only shape one pattern of the intellectual-state relation. Unfortunately, these conventional wisdom holders simply overlooked the unique characteristic of transitional societies that the social structure is never an undiversified one, nor is the pattern of the intellectual-state relation. The dynamism of transitional societies renders limited spaces and opportunities of different of social groups; and this trend in turn shapes different control mechanisms over the society of the ruling authoritarian regime.

The KMT regime was confronted, or created by itself, a transitional society with vigorous dynamism after its retreat to Taiwan Island. Despite the imposition of the martial law and its seemingly effective implementation, the regime still faced varied social forces with different potentials. The control mechanism it used to adopt during the Republican period in mainland only functioned when 
dealing with the pro-regime intellectuals, since this group of people actually was a favorable fraction affiliated to the dominant class without ambitions.

However, as the economy kept booming, the social structure of Taiwan changes rapidly, so do people's minds. The regime's old control mechanism was doomed to fail if it could be improved with the times. Under the socioeconomic transformation, a new cohort of intellectuals emerged and gradually formed a "new class" with self-consciousness who claimed that by virtue of their monopoly of knowledge they had become a new class with significant influence on sociopolitical issues. What they sought were more autonomy, more open public space, and more opportunities for participation rather than barely dependence on some other classes. The critical opposition intellectuals and the younger students on campus shared some similar characteristics of the new class. But the KMT still adopted the rigid thinking when dealing with these new generations of intellectuals. Had the KMT leadership clearly noticed this trend and situation, they would have changed their strategies and tactics of the control mechanism. And had they changed, or even modified, the control mechanism into a more inclusive one, the KMT regime might have had another story.

\section{Fund}

This work is supported by New Faculty Members Start-Up Project Fund of Renmin University of China (14XNF044).

\section{References}

[1] Zhang, X.J. (2008) Jindai Zhongguo De Qiluren: Luo Jialun Pingzhuan. [The Man Taking the Wrong Path in Modern China: A Critical Biography of Luo Jialun.] People's Publishing House, Beijing.

[2] Chen, B.L. (1967) Chen Bulei Huiyilu. [A Memoire of Chen Bulei.] Biographical Literature Publishing, Taipei.

[3] Taylor, J. (2009) The Generalissimo: Chiang Kai-Shek and the Struggle for Modern. Harvard University Press, Cambridge, MA.

[4] Shen, C.Y. (2008) Chiang Kai-Shek's Chief of Staff: Chen Bulei and The Politics of Republican China (1927-1948). Mater Thesis, Tunghai University, Taichung.

[5] Mao, J.Q. (2005) Zhongguo Guomindang Shi. [A Hundred-Year History of Chinese Kuomintang.] Lujiang Publishing House, Xiamen.

[6] Li, Y.N. (1998) Hu Shi and the Kuomintang. Outer Sky Press, New York, 3.

[7] Chow, T.T. (1960) The May Fourth Movement: Intellectual Revolution in Modern China. Harvard University Press, Cambridge, MA.

[8] Schwartz, V. (1986) The Chinese Enlightenment: Intellectuals and the Legacy of the May Fourth Movement of 1919. University of California Press, Berkeley, CA.

[9] Pepper, S. (1978) Civil War in China: The Political Struggle, 1945-1949. University of California, Berkeley, CA.

[10] Pan, G.Z. (2003) Dangguo Tizhi De Pipan. [Critiques of Party-State System.] Daw Shiang Publishing Co., Taipei.

[11] Zhou, W.J. (2008) Zai Taiwan: Guoxue Dashi De 1949. [Life in Taiwan: Masters of 
Traditional Chinese Culture in 1949.] Gold Wall Press, Beijing, 5.

[12] Grieder, J.B. (1970) Hu Shih and the Chinese Renaissance: Liberalism in the Chinese Revolution, 1917-1937. Harvard University Press, Cambridge, MA.

[13] Cohen, M.J. (1988) Taiwan at the Crossroads: Human Rights, Political Development and Social Change on the Beautiful Island. Asian Resource Center, Washington, D.C., 141-160.

[14] Li, X.F. (1987) Taiwan Minzhu Yundong Sishinian. [Four Decades of Democratic Movements in Taiwan.] Independence Evening Post Press, Taipei, 58-59.

[15] Lei, Z. (1978) Memoir of Lei Zhen. The 70s Publishing House, Hong Kong, 58.

[16] Wei, Z.T. (1987) Taiwan's Intellectual Community over the Three Decades. Taiwan Literature and Arts [ Taiwan Wenyi], 106, 62.

[17] Li, A. (1999) Li Ao Huiyilu. [Memoire of Li Ao.] Li Ao Publishing House, Taipei.

[18] Rigger, S. (1999) Politics in Taiwan: Voting for Democracy. Routledge, London \& New York, 110-112.

[19] Roy, D. (2004) Taiwan: A Political History. Cornell University Press, Ithaca, NY, 125.

[20] Marks, T.A. (1998) Counterrevolution in China: Wang Sheng and the Kuomintang. Frank Cass, London.

[21] Deng, P.Y. (1993) Bashi Niandai: Taiwan Xuesheng Yundong Shi. [The Eighties: A History of Taiwan Student Movements.] Qianwei Publishing House, Taipei.

[22] He, J.S., Guan, H.Z., Zhang, L.J. and Guo, C.Q. (1990) Taipei Xueyun. [Taipei Student Movements.] China Times Publishing House, Taipei.

[23] Qiu, W.J. (2003) Taiwan Xuesheng Yundong: 1949-1979. [Taiwan Student Movement: 1949-1979.] Daoxiang Publishing House, Taipei.

[24] Wright, T. (1999) Student Mobilization in Taiwan: Civil Society and Its Discontents. Asian Survey, 39, 986-1008.

[25] Shi, M.X. (1998) Baise Kongbu, Heian Shidai: Taiwan Ren Shounanshi. [White Terror and Dark Ages: A History of Taiwanese People's Suffering.] Avanguard Publishing House, Taipei.

[26] Lai, T.-H., Myers, R.H. and Wei, W. (1991) A Tragic Beginning: The Taiwan Uprising of February 28, 1947. Stanford University Press, Stanford, CA.

[27] Reardon-Anderson, J. (1992) Pollution, Politics, and Foreign Investment in Taiwan: The Lukang Rebellion. M.E. Sharpe, New York.

[28] Gouldner, A.W. (1979) The Future of Intellectuals and the Rise of the New Class. Seabury Press, New York.

[29] Bell, D. (1973) The Coming of Post-Industrial Society: A Venture in Social Forecasting. Basic Books, New York.

[30] Konrad, G. and Szelenyi, I. (1979) The Intellectuals on the Roads to Class Power. Harcourt Brace Jovanovich, New York.

[31] Bourdieu, P. (1990) In Other Words: Essays towards a Reflective Sociology. Stanford University Press, Stanford, CA. 